\title{
SNHG8 is identified as a key regulator in non-small-cell lung cancer progression sponging to miR-542-3p by targeting CCND I/CDK6 [Erratum]
}

Chen C, Zhang Z, Li J, Sun Y. Onco Targets Ther. 2018;11: 6081-6090.

On page 6089, the acknowledgment section was not included:

\section{Acknowledgment}

This study was funded by National Natural Science Foundation of China (No 81600217), Natural Science Foundation of Jiangsu Province (BK20160346), Jiangyin Municipal Transformation of Scientific and Technological Achievements Project of China (No JYKJ3308).
OncoTargets and Therapy

\section{Publish your work in this journal}

OncoTargets and Therapy is an international, peer-reviewed, open access journal focusing on the pathological basis of all cancers, potential targets for therapy and treatment protocols employed to improve the management of cancer patients. The journal also focuses on the impact of management programs and new therapeutic agents and protocols on patient perspectives such as quality of life, adherence and satisfaction. The manuscript management system is completely online and includes a very quick and fair peer-review system, which is all easy to use. Visit http://www.dovepress.com/testimonials.php to read real quotes from published authors. 